\title{
PRZYCZYNEK DO BADAŃ NAD KRZEMIENIARSTWEM GRUPY LUPAWSKIEJ KPL
}

\section{CONTRIBUTION TO THE STUDY OF THE FLINT WORKING OF THE ŁUPAWA GROUP OF TRB}

\author{
Lucyna Domańska \\ Instytut Archeologii, Uniwersytet Łódzki \\ ul. Uniwersytecka 3, 90-137 Łódź, Poland \\ lucynad@uni.lodz.pl
}

\begin{abstract}
Discussion in the article concentrates mainly on the relationship between flint working of the communities of the Lupawa group and populations representing the Funnel Beaker culture in Kujawy. Such a comparisons became possible with the discoveries at Wilkostowo 23/24 site, com. Aleksandrów Kujawski.
\end{abstract}

KEY WORDS: Funnel Beaker culture, Łupawa group, flint working.

W badaniach nad krzemieniarstwem grupy łupawskiej kultury pucharów lejkowatych (dalej: KPL) podstawowe znaczenie mają prace wykopaliskowe Profesor Dobrochny Jankowskiej w rejonie Łupawy, w tym szczególnie odkrycia na stanowisku Poganice 4, gm. Potęgowo (Jankowska 1973, 1975, 1980, 1990). Wytwory krzemienne z osady w Poganicach i z cmentarzysk megalitycznych w rejonie Łupawy były przedmiotem kilku opracowań (Balcer 1983; Domańska 1974, 1987).

Na podstawie wyników cytowanych wyżej prac wydzielony został tzw. przemysł łupawski (Balcer 1983). Jego odrębność w stosunku do krzemieniarstwa innych grup KPL miała wynikać przede wszystkim ze specyfiki krzemienia pomorskiego. Surowiec ten wymuszał stosowanie na dużą skalę metody łuszczniowej, a większość wytworów miała niewielkie rozmiary.

Celem niniejszego artykułu jest opisanie zbadanych relacji między krzemieniarstwem społeczności grupy łupawskiej i kujawskich populacji KPL. Możliwość dokonania takich porównań stworzyły odkrycia na stanowisku Wilkostowo 23/24. Stanowią one obecnie najważniejszą bazę źródłową dla charakterystyki krzemieniarstwa horyzontu klasycznowióreckiego KPL w strefie wielkodolinnej Niżu Polskiego (Domańska 2013). 

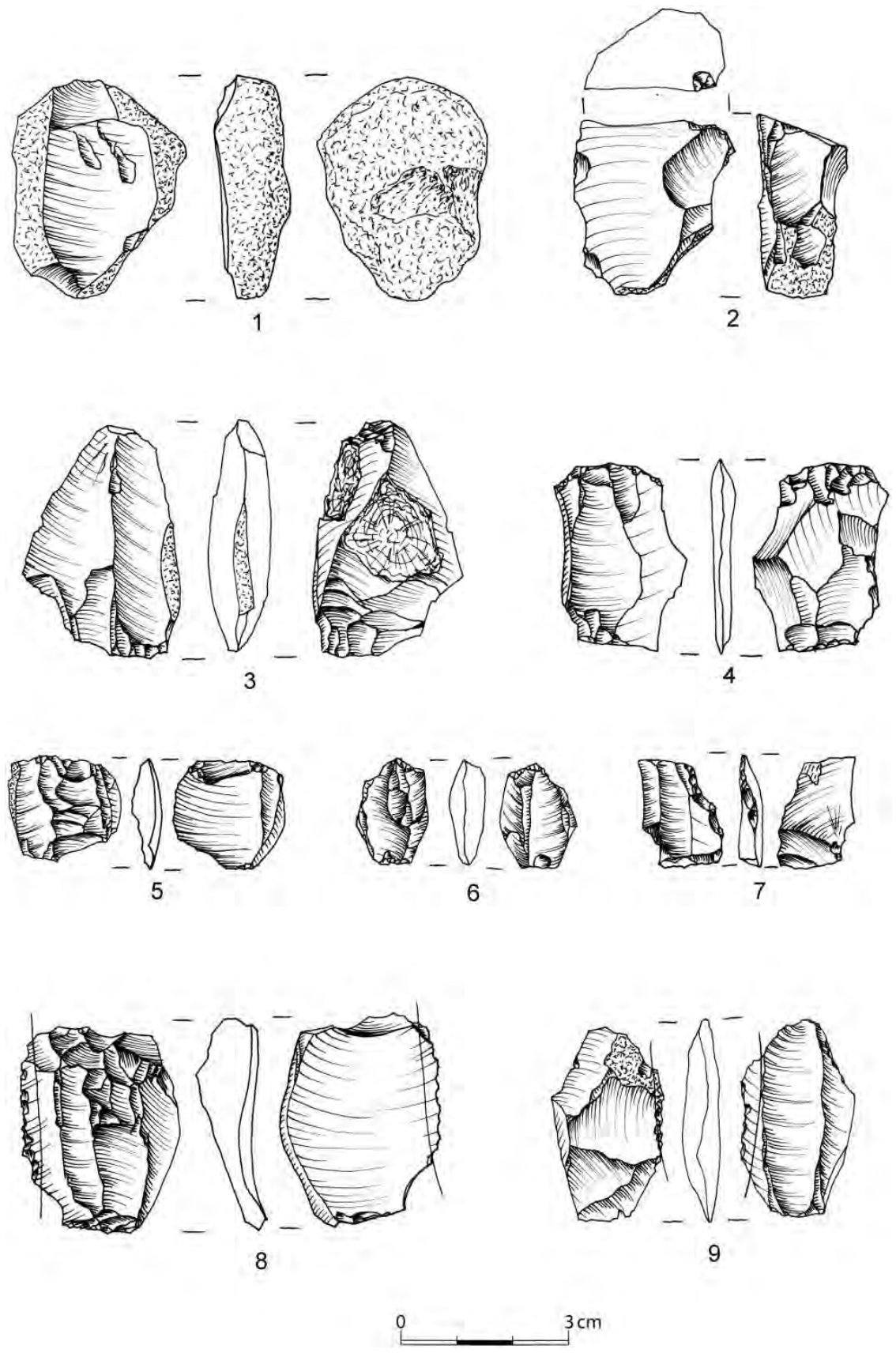

Ryc. 1. Wilkostowo 23/24, gm. Aleksandrów Kujawski. 1-6 - łuszcznie; 7-9 - łuszcznie retuszowane. 1-2, 4, 6, 9 - krzemień baltycki; 5 - krzemień pomorski; 3 - przepalony

Fig. 1. Wilkostowo, site 23/24, com. Aleksandrów Kujawski. 1-6 - splintered pieces; 7-9 - retouched splintered pieces. 1-2, 4, 6, 9 - Baltic flint; 5 - Pomeranian flint; 3 - burnt 


\section{WILKOSTOWO 23/24}

Na stanowisku odkryto 1031 artefaktów krzemiennych, spośród których zdecydowana większość niewątpliwie może być przypisana KPL. Cechą szczególną tych materiałów jest ich struktura surowcowa. Oprócz zdecydowanej dominacji krzemienia bałtyckiego $(66,4 \%)$ wyraźnie zaznacza się udział krzemienia wołyńskiego $(8,6 \%)$ i czekoladowego (8\%).

W grupie wytworów z krzemienia bałtyckiego można wyróżnić kilka odmian i ich wariantów, m.in. kilkanaście wytworów z krzemienia pomorskiego (ten ostatni surowiec traktowany jest przez wielu badaczy jako odmiana krzemienia bałtyckiego - por. Balcer 1983; Dmochowski 2005; Domańska 1983, 1987, 2013; Wąs [w druku]). Zróżnicowanie krzemienia bałtyckiego nie przekłada się jednak na specyficzne wykorzystanie którejś z jego odmian w całokształcie miejscowej obróbki krzemienia.

Grupą zdecydowanie dominującą ilościowo w omawianych materiałach są produkty eksploatacji łuszczniowej (ryc. 1:1-6). Stanowią one łącznie prawie połowę inwentarza (43,3\%). Metodę łuszczniową stosowano w dwu zasadniczych celach, tj. do obróbki miejscowego krzemienia bałtyckiego oraz do przekształcania wytworów z surowców południowych - głównie makrolitów z krzemienia wołyńskiego.

W grupie eksploatacji łuszczniowej ok. $80 \%$ łuszczni i odłupków łuszczniowych wykonano z krzemienia bałtyckiego. Wśród łuszczni zdecydowanie dominują okazy o dwu biegunach, a ich rozmiary rzadko przekraczają $35 \mathrm{~mm}$. Na większości odłupków łuszczniowych $\mathrm{z}$ tego surowca występują wyłącznie negatywy łuszczniowe. Potwierdza to ich związek z obróbką krzemienia bałtyckiego.

Produkty eksploatacji odłupkowej ilościowo ustępują grupie eksploatacji łuszczniowej. Stanowią one ok. 15\% całości inwentarza, przy czym ich widoczną cechą jest wyraźny synkretyzm technologiczny. Wskazuje to na polimorficzność wytwórczości krzemieniarskiej, w której współwystępują różne zabiegi (intencjonalna produkcja odłupków, przekształcanie innych narzędzi, kształtowanie form czworościennych), a ich efektem są odłupki.

Zdecydowanie najmniej liczna w omawianym inwentarzu jest grupa eksploatacji wiórowej. Wytwory tej grupy stanowią zaledwie niewiele ponad $2 \%$ całości materiałów.

Udział grupy narzędzi w ogólnej strukturze inwentarza jest stosunkowo wysoki i sięga niemal $18 \%$. W grupie tej umieszczono narzędzia typologiczne (konwencjonalne) i narzędzia użytkowe. Te ostatnie zdecydowanie dominują w omawianym inwentarzu. Stanowią one ok. 70\% wszystkich narzędzi. Jedynie 30\% stanowią narzędzia typologiczne. W skład narzędzi typologicznych wchodzą drapacze (ryc. 2), przekłuwacze, wiertniki, półtylczaki, wiórowce (ryc. 3), trapezy i grociki (ryc. 4).

W grupie narzędzi użytkowych około $40 \%$ okazów nie ma żadnego retuszu, a występujące na ich krawędziach wyłuski lub wyświecenia są efektem ich intensywnego użytkowania. Na takie narzędzia przeznaczano zarówno wióry, odłupki, jak i produkty eksploatacji łuszczniowej (ryc. 1:7-9). Często półsurowiec pochodził też 


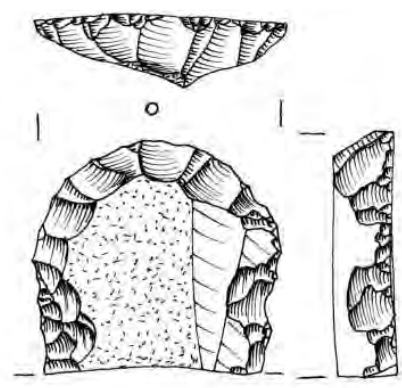

1
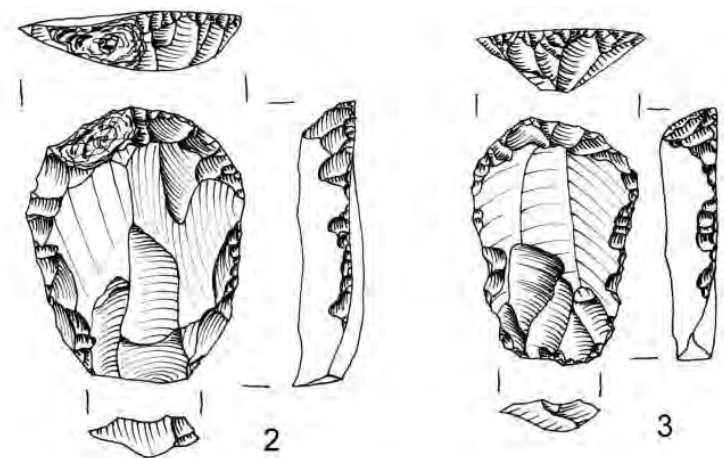
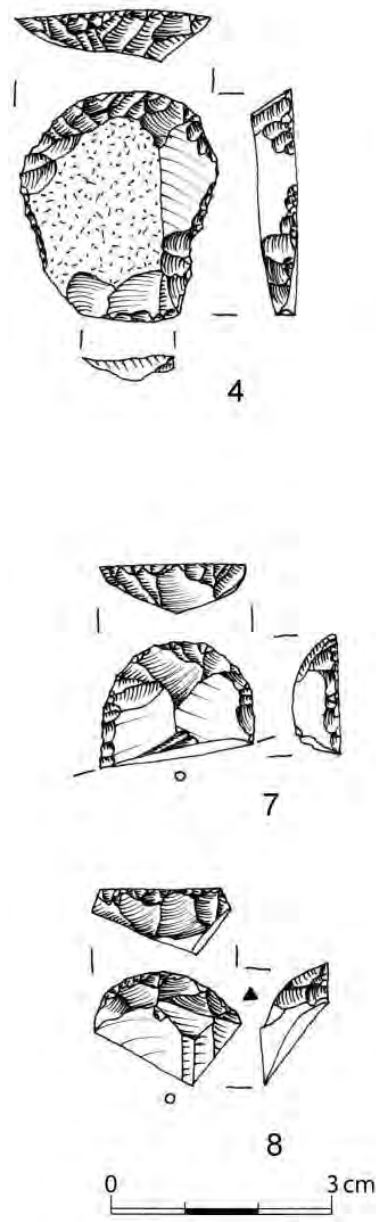
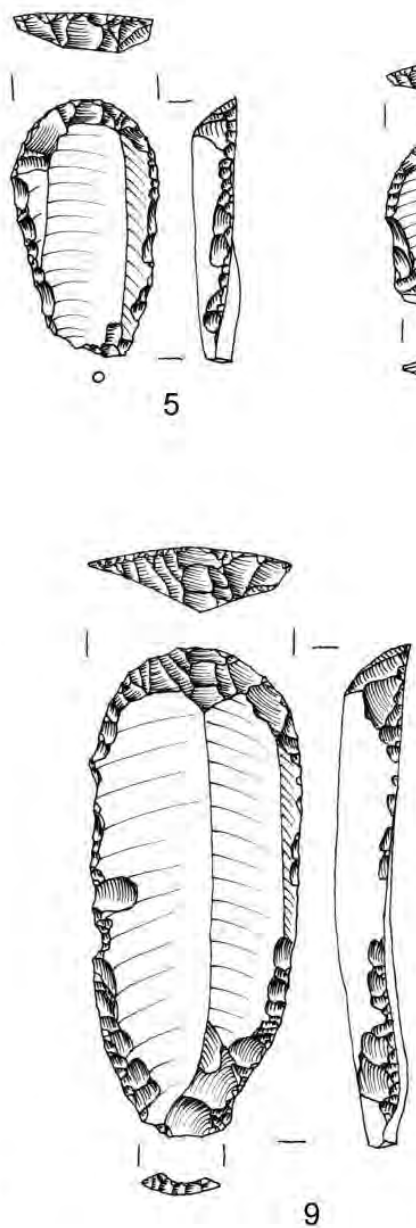

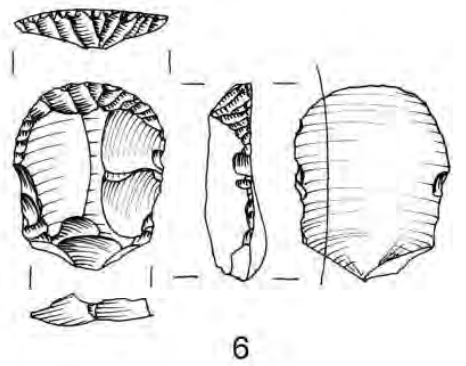

Ryc. 2. Wilkostowo 23/24, gm. Aleksandrów Kujawski. Drapacze. 1-10 - krzemień wołyński

Fig. 2. Wilkostowo, site 23/24, com. Aleksandrów Kujawski. End scrapers. 1-10 - Volhynian flint 

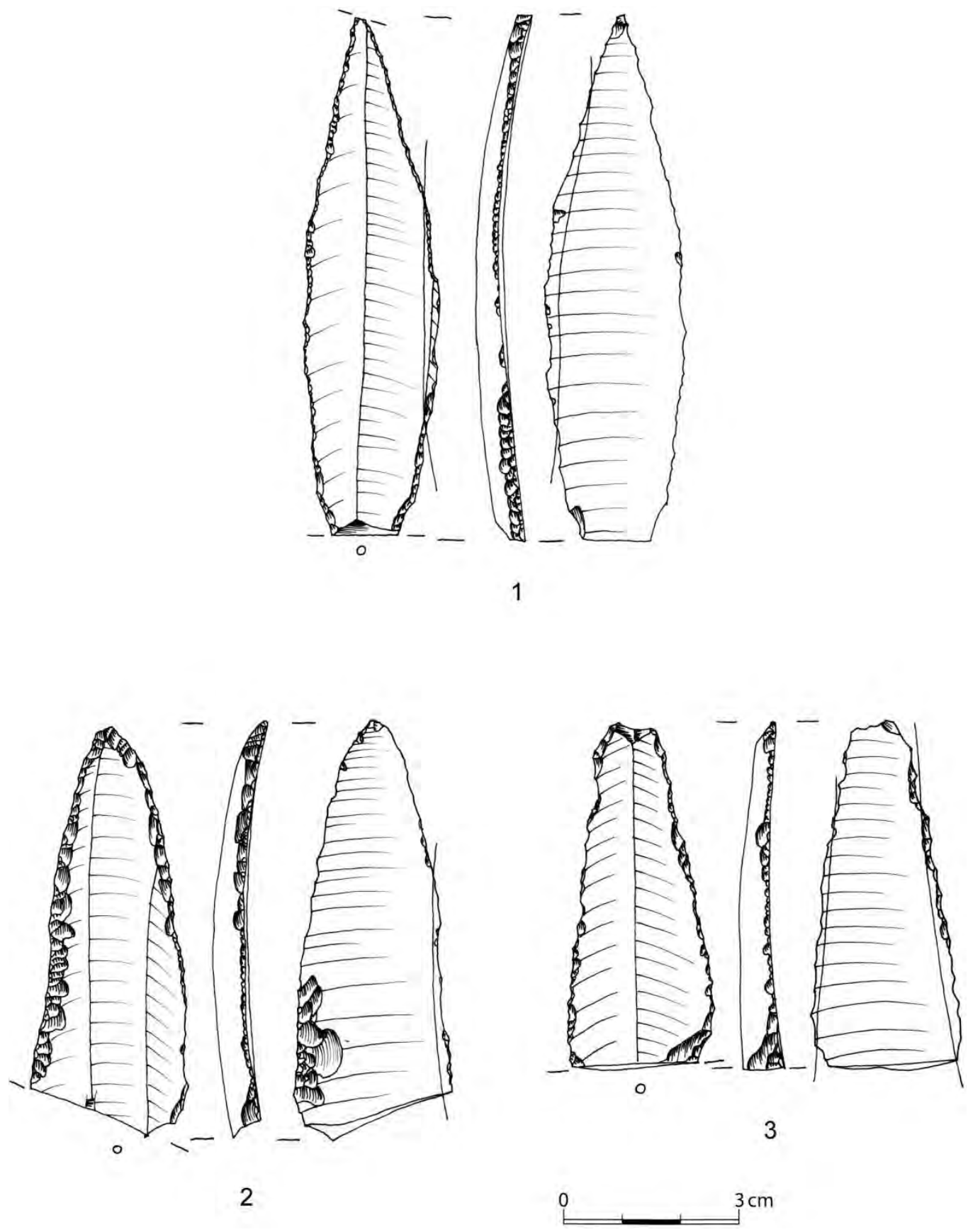

Ryc. 3. Wilkostowo 23/24, gm. Aleksandrów Kujawski. Wiórowce zbieżne. 1-3 - krzemień wołyński

Fig. 3. Wilkostowo, site 23/24, com. Aleksandrów Kujawski. Convergent retouched blades. 1-3 - Volhynian flint 


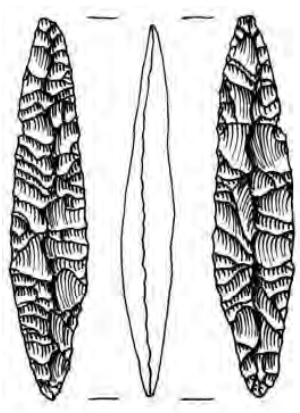

1

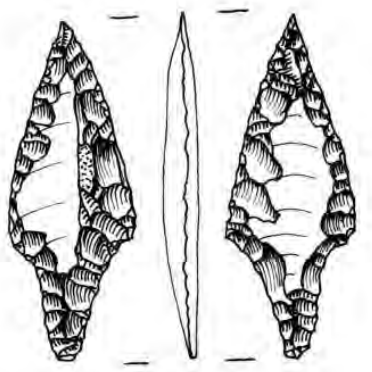

2

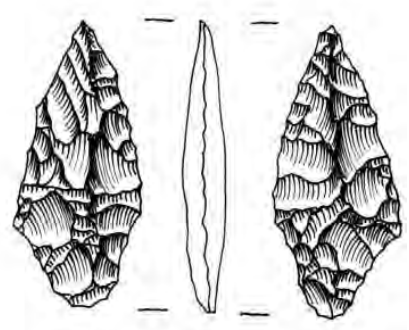

3

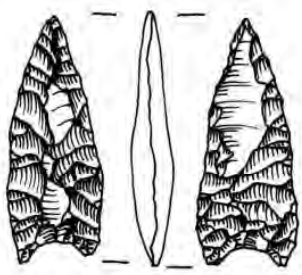

4

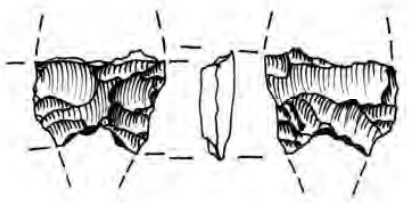

5

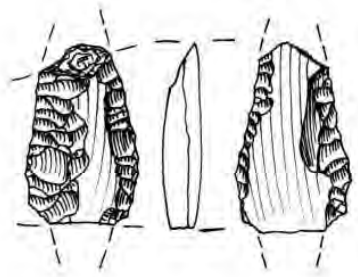

6

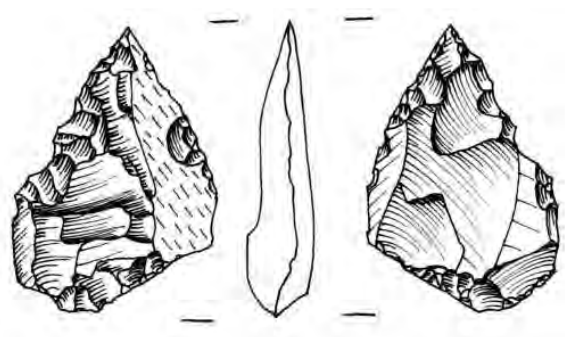

7

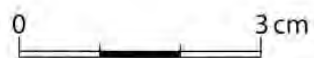

Ryc. 4. Wilkostowo 23/24, gm. Aleksandrów Kujawski. 1-6 - grociki; 7 - półprodukt grocika; 1-2, 6 - krzemień wołyński; 3-5, 7 - krzemień bałtycki

Fig. 4. Wilkostowo, site 23/24, com. Aleksandrów Kujawski. 1-6 - arrowheads, 7 - half-product of a arrowhead; 1-2, 6 - Volhynian flint; $3-5,7$ - Baltic flint 
z przekształcania innych form, np. narzędzi makrolitycznych. Pozostałych $60 \%$ tej grupy narzędzi było przygotowanych za pomocą różnych retuszy, którymi opracowywano tylko fragmenty krawędzi. Do produkcji tych narzędzi wykorzystywano półsurowiec zróżnicowany zarówno pod względem technologicznym, jak i metrycznym.

Jako osobną grupę wydzielono siekierki szlifowane. Zachowały się w całości tylko dwie: siekierka czworościenna z krzemienia wołyńskiego oraz ciosło z krzemienia bałtyckiego. Odkryto natomiast stosunkowo liczne odłupki zwykłe i łuszczniowe $\mathrm{z}$ powierzchniami szlifowanymi. Przeważają wśród nich odłupki odbite od siekierek z krzemienia bałtyckiego, zarejestrowano też odłupki z siekierek z krzemienia świeciechowskiego i wołyńskiego.

\section{POGANICE 4}

Kluczowymi materiałami krzemiennymi grupy łupawskiej są wytwory ze stanowiska Poganice 4, gm. Potęgowo. Na stanowisku tym pozyskano ponad 16 tysięcy okazów (Domańska 1974, 1987).

Surowiec użyty do produkcji wyrobów na tym stanowisku uderza swą jednolitością. Wykorzystywano niemal wyłącznie krzemień bałtycki. Z innych surowców zarejestrowano tylko jeden odłupek z krzemienia wołyńskiego (Balcer 1983).

$\mathrm{W}$ inwentarzu z Poganic zdecydowanie dominują okazy z odmiany krzemienia bałtyckiego, określanego mianem pomorskiego (Balcer 1983; Dmochowski 2005; Domańska 1983, 1987, 2013; Wąs [w druku]), który w dużych ilościach występuje w najbliższym sąsiedztwie osady. Mniejsze znaczenie w omawianych materiałach miały inne rodzaje materiału lokalnego, wśród których przeważa surowiec o barwie jasnoszarej. W prezentacji materiałów krzemiennych z Poganic te dwie odmiany traktowane będą rozłącznie ze względu na to, iż każda z nich zajmowała inną pozycję w lokalnej wytwórczości w ujęciu technologicznym.

Krzemień pomorski w materiałach z Poganic 4 osiąga wskaźnik równy 97,6\% całości inwentarza. Do grupy tej włączono także wytwory przepalone. Strukturę surowcową uzupełniają okazy z innych odmian krzemienia bałtyckiego - 395 zabytków ( $2,4 \%$ wszystkich wytworów).

Zdecydowanie dominującą ilościowo grupą w inwentarzu z Poganic są produkty eksploatacji łuszczniowej. Stanowią one łącznie niemal połowę wszystkich wytworów z krzemienia pomorskiego (48,3\%). Grupę tę tworzą odłupki łuszczniowe $(38,3 \%)$ oraz łuszcznie ( $10 \%$ całości inwentarza - ryc. 5). Wśród łuszczni najliczniejsze są okazy dwustronne dwubiegunowe. Rozmiary większości łuszczni i odłupków łuszczniowych mieszczą się w przedziale: długość - 10-40 mm, szerokość - 10-30 mm.

Kolejne miejsce pod względem udziału ilościowego zajmują fragmenty otoczaków z krzemienia pomorskiego oraz zniszczone, poprzez intensywne przepalenie, wytwory z tego surowca. Łącznie stanowią one niemal $40 \%$ całości inwentarza. 

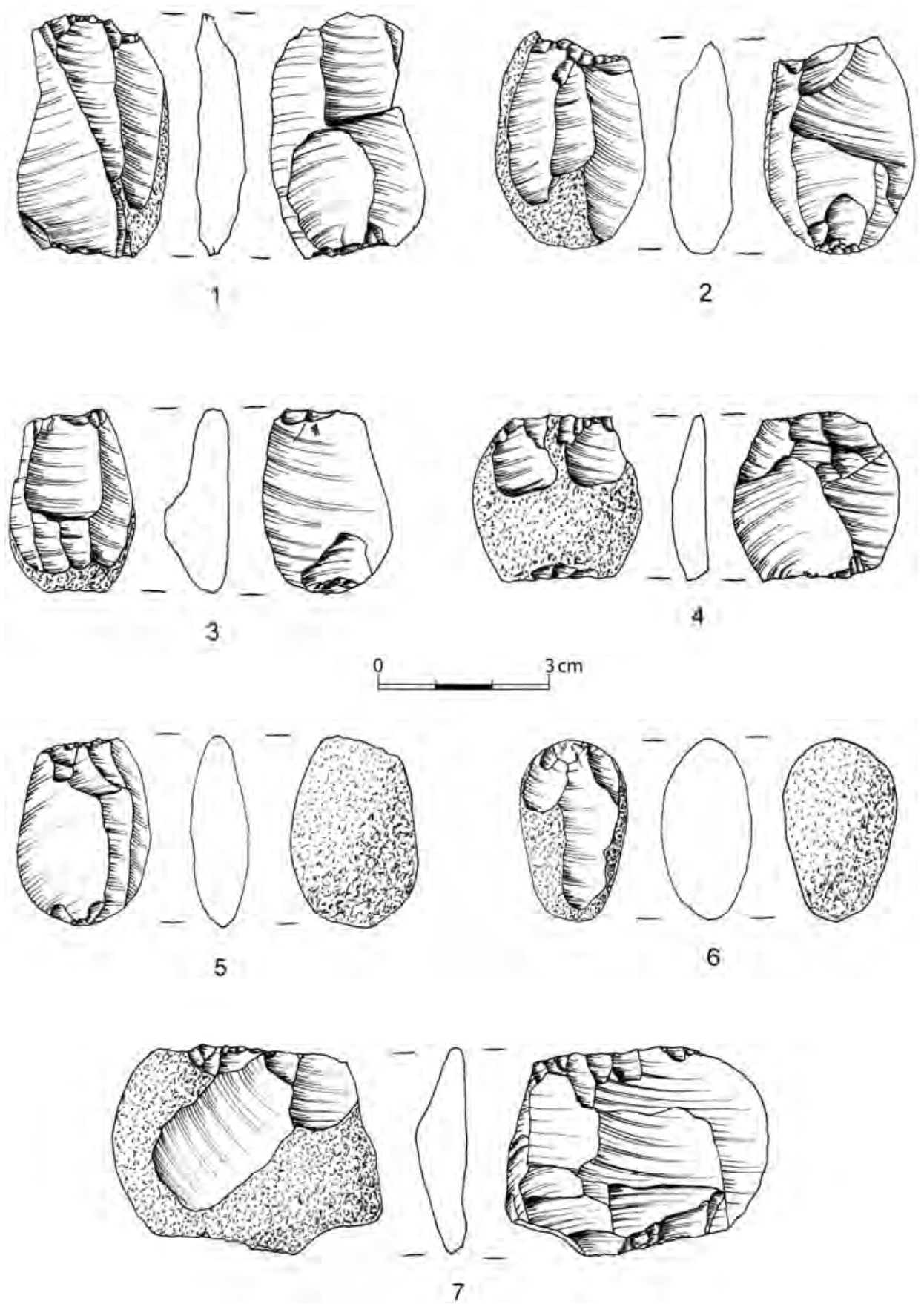

Ryc. 5. Poganice 4, gm. Potęgowo. Łuszcznie. 1-7 - krzemień pomorski

Fig. 5. Poganice, site 4, com. Potęgowo. Splintered pieces. 1-7 - Pomeranian flint 


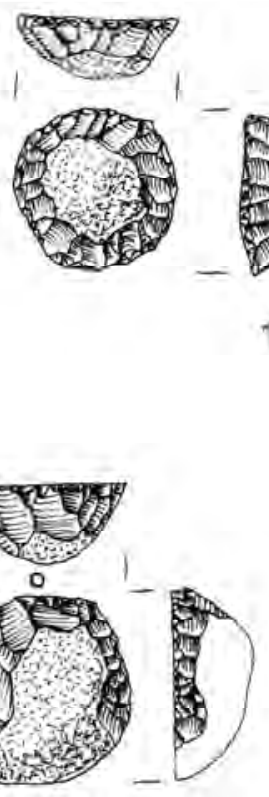

3

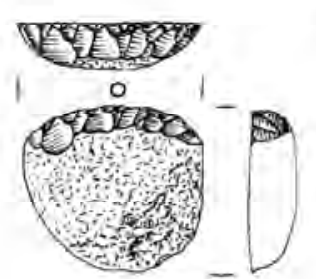

4

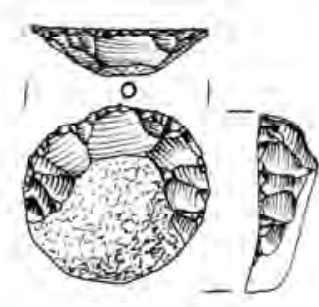

5

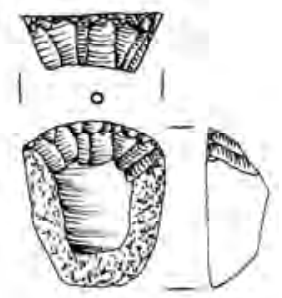

6
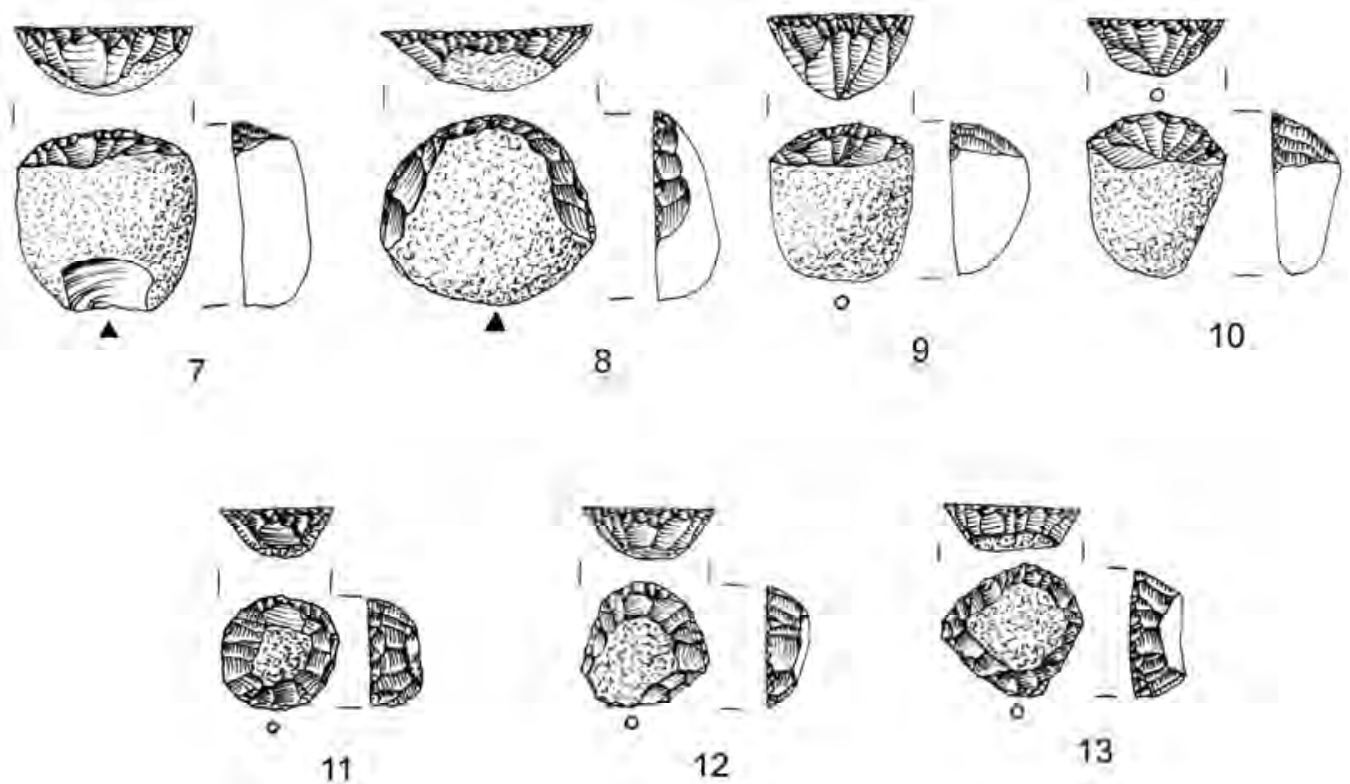

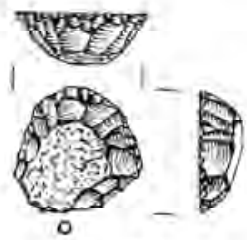

12

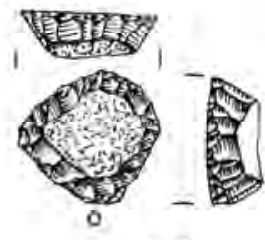

13

Ryc. 6. Poganice 4, gm. Potęgowo. Drapacze. 1-13 - krzemień pomorski

Fig. 6. Poganice, site 4, com. Potęgowo. End scrapers. 1-13-Pomeranian flint 

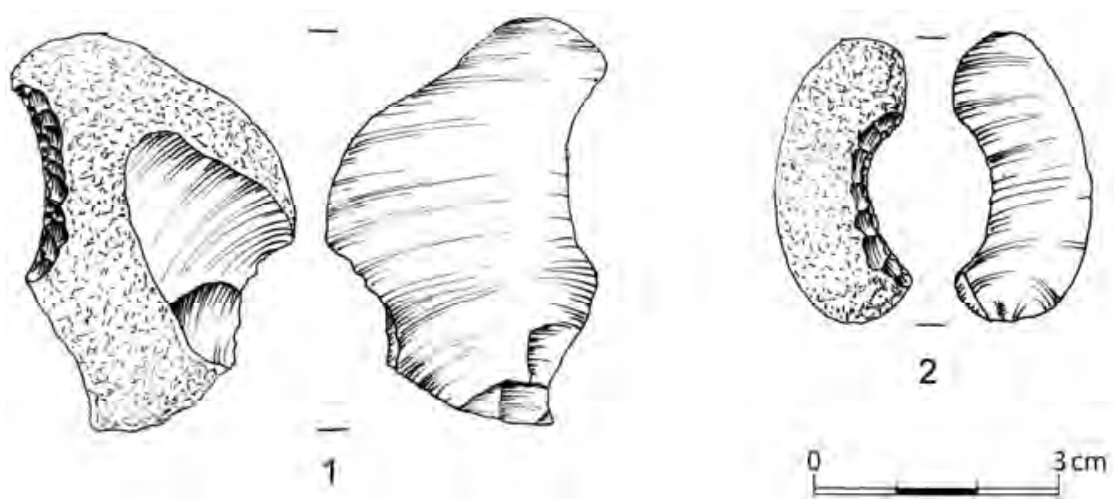

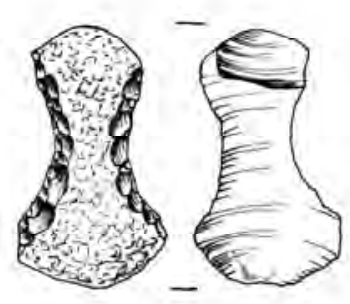

3
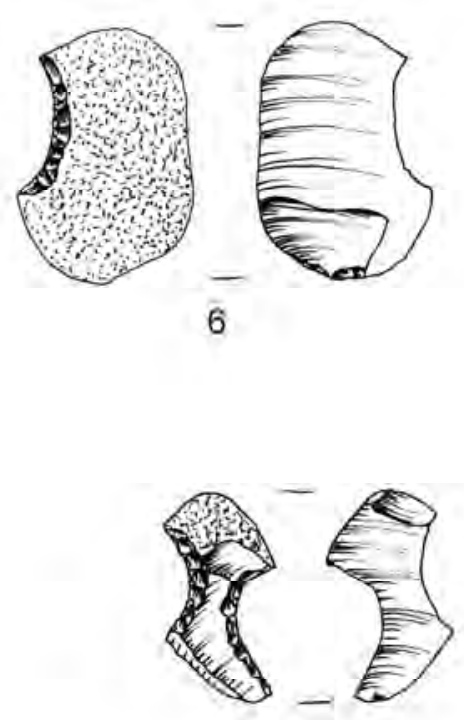

8

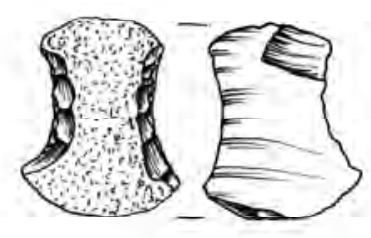

4

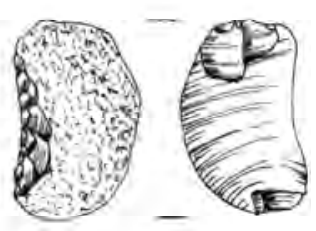

5
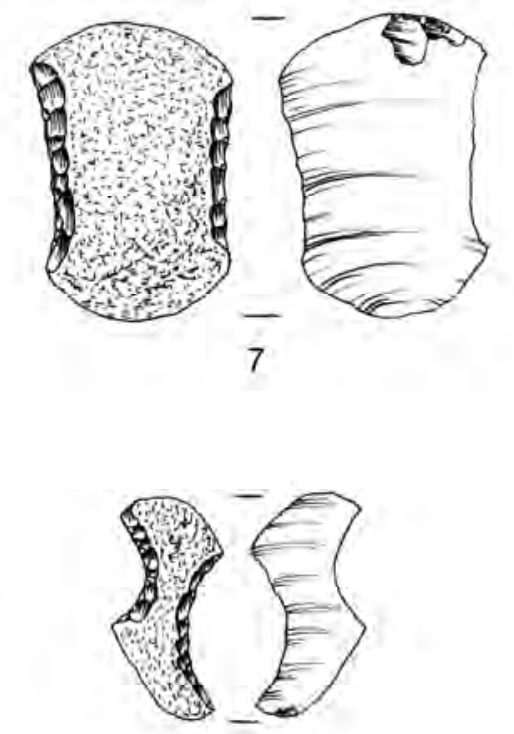

9

Ryc. 7. Poganice 4, gm. Potęgowo. Obłęczniki. 1-9 - krzemień pomorski

Fig. 7. Poganice, site 4, com. Potęgowo. Notched blade. 1-9- Pomeranian flint 


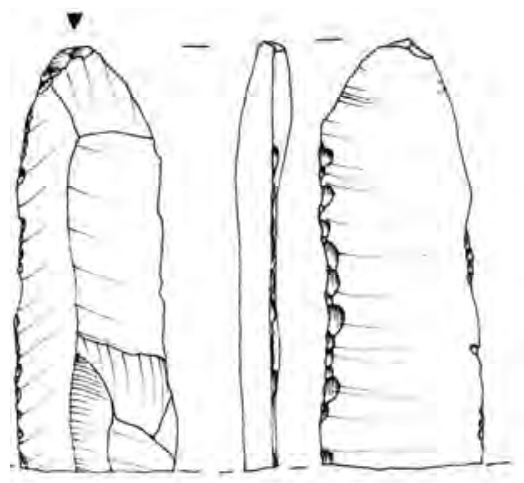

1
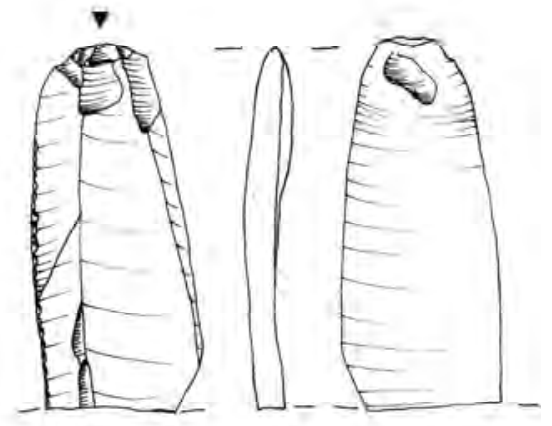

2

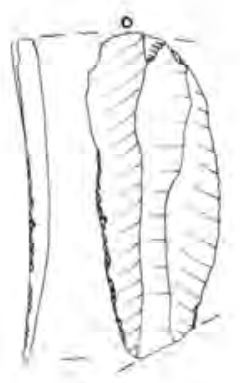

3
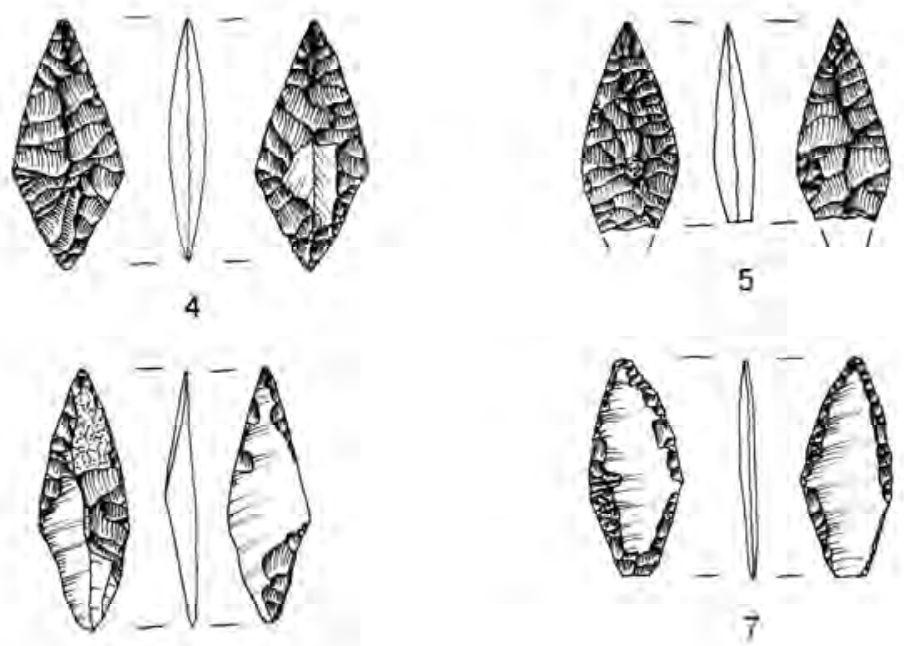

6

Ryc. 8. Poganice 4, gm. Potęgowo. 1 - wiórowiec; 2-3 - wióry mikroretuszowane; 4-7 - grociki; 1-3-krzemień bałtycki; 4-7-krzemień pomorski

Fig. 8. Poganice, site 4, com. Potęgowo. 1 - retouched blade; 2-3 - microretouched blades; 4-7 - arrowheads; $1-3$ - Baltic flint; 4-7 - Pomeranian flint 
Strukturę ilościowo-jakościową wytworów z krzemienia pomorskiego uzupełniają narzędzia. Zidentyfikowano ogółem 1943 okazy, co stanowi 12,7\% wytworów $\mathrm{z}$ tego surowca.

W grupie narzędzi z krzemienia pomorskiego najliczniejsze są narzędzia typologiczne $(82,1 \%)$. W grupie tej zdecydowanie dominują drapacze (ryc. 6), stanowią one $74 \%$ wszystkich narzędzi. Do ich produkcji wykorzystywano najczęściej odłupki korowe pochodzące z rozbicia otoczaków na dwie części.

Kolejne miejsce zajmują obłęczniki (6,4\% grupy narzędzi). Są to okazy z głębokimi wnękami (ryc. 7). Przeważają obłęczniki jednownękowe.

Ostatnią z podstawowych grup narzędzi typologicznych są grociki (ryc. 8:4-7). Dominują wśród nich okazy liściowate, o przekroju soczewkowatym, łuskane dwustronnie, powierzchniowo. Znaleziono także okazy łuskane wyłącznie przykrawędnie, zarówno dwustronnie, jak i jednostronnie.

Zestaw narzędzi typologicznych z krzemienia pomorskiego uzupełniają pojedyncze okazy przekłuwaczy i wiertników. Warto dodać, że w grupie narzędzi z krzemienia pomorskiego narzędzia użytkowe stanowią 12,7\% tej grupy. Są to retuszowane okazy z grupy eksploatacji łuszczniowej.

Surowcem egzotycznym na tym stanowisku są odmiany krzemienia bałtyckiego niewystępujące w pobliżu osady. Dominuje wśród nich, jak wyżej zaznaczono, surowiec o barwie jasnoszarej. Sprowadzano z niego gotowy półsurowiec i narzędzia. Wśród narzędzi na uwagę zasługują wiórowce (ryc. 8:1), wióry użytkowe (ryc. 8:2-3) oraz siekierki. Jednak należy podkreślić, iż w materiałach z Poganic 4 wystąpiły one w niewielkich ilościach; szczególnie dotyczy to narzędzi wiórowych.

\section{ANALIZA PORÓWNAWCZA INWENTARZY Z WILKOSTOWA 23/24 I POGANIC 4}

$\mathrm{Na}$ obu stanowiskach dominuje krzemień lokalny (Wilkostowo 23/24-66,4\%, Poganice 4 - niemal $100 \%$ ). Obie osady różnią się natomiast strukturą surowców importowanych. W materiałach z Wilkostowa 23/24 wyraźnie zaznacza się obecność surowców południowych, głównie krzemienia wołyńskiego i czekoladowego. Z kolei na stanowisku w Poganicach 4 import surowców pozalokalnych odgrywał niewielką rolę i dotyczył prawie wyłącznie surowców występujących na Niżu.

W zakresie struktury technologicznej oba inwentarze są do siebie zbliżone. Dominuje w nich grupa eksploatacji łuszczniowej (Wilkostowo 23/24-43,3\%, Poganice 4-48,3\%). Metodę łuszczniową wykorzystywano przede wszystkim do obróbki lokalnego surowca. Na stanowisku Wilkostowo 23/24 używano jej również w procesie przekształcania wytworów makrolitycznych z surowców importowanych. W materiałach z Poganic 4 zaobserwowano również, choć na mniejszą skalę, złuszczanie niektórych wytworów z krzemienia pomorskiego. 
Omawiane inwentarze różnią się natomiast udziałem klasycznych metod rdzeniowania. Zdecydowanie częściej wykorzystywano je w Wilkostowie 23/24. Metody klasyczne stosowano zarówno w obróbce krzemienia bałtyckiego, jak i surowców importowanych. Te ostatnie eksploatowane były na terenie osady za pomocą metody odłupkowej, wióry zaś wytwarzane były poza stanowiskiem.

Klasyczne metody rdzeniowania na osadzie w Poganicach 4 wykorzystywane były sporadycznie, szczególnie odnosi się to do krzemienia pomorskiego. Rdzeń odłupkowy z tego surowca przerobiony na łuszczeń potwierdza miejscową produkcję odłupków. Jednak w skali całego inwentarza ich udział ilościowy był niewielki. Nieco liczniejsze były produkty klasycznych metod rdzeniowania w odniesieniu do innych odmian krzemienia bałtyckiego. Wióry i narzędzia wiórowe wytwarzane były poza osadą, podobnie jak tego typu wytwory z surowców egzotycznych w Wilkostowie 23/24.

$\mathrm{Na}$ obu stanowiskach znaleziono te same kategorie narzędzi, różny jest jednak ich udział ilościowy. W inwentarzu z Wilkostowa 23/24 dominują narzędzia użytkowe, tj. atypowo retuszowane wióry, odłupki i wytwory grupy eksploatacji łuszczniowej. Osiągają one wskaźnik równy 70,2\%. Wśród narzędzi typologicznych najliczniejsze są drapacze, kolejne miejsca zajmują półtylczaki, wiórowce i grociki. Z kolei w materiałach z Poganic 4 najliczniejsze są narzędzia typologiczne - stanowią one $80,2 \%$ grupy narzędzi. Dominują wśród nich drapacze (74\% wszystkich narzędzi). Wykonywano je głównie na połówkach otoczaków z krzemienia pomorskiego.

\section{PODSUMOWANIE}

Porównując materiały krzemienne z Wilkostowa 23/24 i Poganic 4, można zaobserwować zarówno duże podobieństwa między nimi, jak i pewne różnice. Zespoły te łączy przede wszystkim dobre rozpoznanie lokalnych surowców krzemiennych oraz ich intensywne wykorzystywanie, a w zakresie technologii - dominacja metody łuszczniowej.

Do najważniejszych różnic między analizowanymi stanowiskami należy stosunkowo wysoki udział surowców południowych (krzemień wołyński i czekoladowy) W strukturze surowcowej inwentarza z Wilkostowa 23/24 oraz wyraźny udział w strukturze technologicznej tych materiałów wytworów grupy eksploatacji odłupkowej i wiórowej. Z kolei na osadzie w Poganicach 4 wykorzystywano wyłącznie (jedyny wyjątek to odłupek wykonany prawdopodobnie z krzemienia wołyńskiego) różne rodzaje krzemienia bałtyckiego, spośród których decydujące znaczenie miał krzemień pomorski. Klasyczne metody rdzeniowania stosowano rzadko.

$\mathrm{Na}$ obu stanowiskach występują niemal te same kategorie narzędzi, inny jest natomiast ich udział ilościowy. Dla osady w Poganicach 4 szczególnie charakterystyczne są drapacze odłupkowe z krzemienia pomorskiego. Z kolei materiały z Wilkostowa 23/24 wyróżniają się obecnością makrolitów z surowców południowych, w tym wiórowców zbieżnych z krzemienia wołyńskiego. 
Wydaje się, iż zaprezentowane elementy wspólne analizowanych inwentarzy można uznać za wyznaczniki krzemieniarstwa niżowych społeczności KPL. Cechą charakterystyczną tego krzemieniarstwa byłaby jego elastyczność i łatwość w dostosowywaniu się do zróżnicowanych warunków ekologicznych i kulturowych (Domańska 2013). Wskazuje na to m.in. popularność metody łuszczniowej w obróbce miejscowych surowców krzemiennych. W zależności zaś od potrzeb zestaw wytworów grupy eksploatacji łuszczniowej i odłupkowej uzupełniano o importy wiórów i narzędzi wiórowych z surowców południowych (szczególnie liczne w Wilkostowie 23/24) lub z lepszych odmian krzemienia bałtyckiego (nieliczne narzędzia wiórowe w Poganicach 4 (Balcer 1983; Domańska 1974, 1987; Wierzbicki 1999).

Zaobserwowane różnice ilościowe $\mathrm{w}$ grupie narzędzi między oboma stanowiskami wynikają zapewne z odmiennych strategii gospodarczych. Na osadzie w Wilkostowie 23/24 podstawowe znaczenie miały zajęcia rolnicze (Rzepecki 2014). Znajdują one odzwierciedlenie w zestawie narzędzi krzemiennych: wiórowce, wióry użytkowe, okazy z wyświeceniem żniwnym. $Z$ kolei dominujące w grupie narzędzi na osadzie w Poganicach 4 liczne drapacze wydają się związane $z$ dominującą rolą hodowli w gospodarce mieszkańców tej osady (Wierzbicki 1999). Część z nich była też najprawdopodobniej wytwarzana na potrzeby innych osad (Balcer 1983).

Warto podkreślić, że uchwycone różnice między analizowanymi materiałami w znacznej części wynikają z użytkowania odmiennych rodzajów krzemienia bałtyckiego. Wydaje się, iż najpoważniejsze znaczenie należy przypisać elementom wspólnym w tych materiałach. Chodzi tu o sposoby eksploatacji surowców lokalnych i egzotycznych. Te pierwsze obrabiane były na miejscu, głównie z wykorzystaniem metody łuszczniowej, rzadziej odłupkowej. Surowce egzotyczne (krzemienie południowe, jak również pewne odmiany krzemienia bałtyckiego) sprowadzane były na teren osad najczęściej w postaci półsurowca lub gotowych narzędzi. Ta ostatnia uwaga dotyczy przede wszystkim narzędzi żniwnych.

\section{BIBLIOGRAFIA}

Balcer B.

1983 Wytwórczość narzędzi krzemiennych $w$ neolicie ziem polskich. Wrocław-WarszawaKraków-Gdańsk-Łódź: Zakład Narodowy im. Ossolińskich, Wydawnictwo Polskiej Akademii Nauk.

Dmochowski P.

2005 A new classification of erratic flint from western Poland. W: A. Wiśniewski, T. Płonka, J. Burdukiewicz (red.), The stone. Technique and technology (s. 217-226). Wrocław: Uniwersytet Wrocławski, Instytut Archeologii, SKAM Stowarzyszenie Krzemieniarskie.

Domańska L.

1974 Materiały krzemienne z osady kultury pucharów lejkowatych w Poganicach pow. Słupsk, stanowisko 4 (Uwagi wstępne). Koszalińskie Zeszyty Muzealne, 4, s. 13-28. 
Domańska L.

1983 Wybrane zagadnienia krzemieniarstwa strefy nadmorskiej $\mathrm{w}$ epoce kamienia. W: T. Malinowski (red.), Problemy epoki kamienia na Pomorzu (s. 217-228). Słupsk: Wyższa Szkoła Pedagogiczna w Słupsku.

Domańska L.

1987 Wytwórczość krzemieniarska grupy łupawskiej kultury pucharów lejkowatych. Acta Universitatis Lodziensis. Folia Archaeologica, 8, s. 17-60.

Domańska L.

2013 Krzemieniarstwo horyzontu klasycznowióreckiego kultury pucharów lejkowatych na Kujawach. Instytut Archeologii Uniwersytetu Łódzkiego, Fundacja Uniwersytetu Łódzkiego, Łódź.

Jankowska D.

1973 Sprawozdanie z prac wykopaliskowych na osadzie kultury pucharów lejkowatych w Poganicach, pow. słupski, stanowisko 4, w 1971 roku. Koszalińskie Zeszyty Muzealne, 2, s. 229-236.

Jankowska, D.

1975 Sprawozdanie z prac wykopaliskowych na stanowisku 4 w Poganicach, pow. Słupsk, w 1973 roku. Koszalińskie Zeszyty Muzealne, 4, s. 3-12.

Jankowska D.

1980 Kultura pucharów lejkowatych na Pomorzu Środkowym. Grupa lupawska. Poznań: Wydawnictwo Naukowe UAM.

Jankowska D.

1990 Społeczności strefy poludniowo-zachodniobaltyckiej $w$ dobie neolityzacji. Poznań: Wydawnictwo Naukowe UAM.

Rzepecki S.

2014 Wilkostowo 23/24. Neolityczny kompleks osadniczy. Łódź: Instytut Archeologii Uniwersytetu Łódzkiego, Fundacja Uniwersytetu Łódzkiego.

Wąs M.

[w druku] Krzemień pomorski w pradziejach Pomorza Gdańskiego. W: B. Matraszek, S. Sałaciński (red.), Krzemień narzutowy w pradziejach. Studia nad gospodarka surowcami krzemiennymi w pradziejach (t. 8).

Wierzbicki J.

1999 Lupawski mikroregion osadniczy ludności kultury pucharów lejkowatych. Poznań: Wydawnictwo Naukowe UAM.

\section{CONTRIBUTION TO THE STUDY OF THE FLINT WORKING OF THE ŁUPAWA GROUP OF TRB}

\section{Su m mary}

The most essential for the study of the flint working of the Łupawa group of the Funnel Beaker culture (hereinafter referred to as TRB from German Trichterbecherkultur) appear to be excavations led by Professor Dobrochna Jankowska in the area of Łupawa, especially the materials unearthed at site Poganice 4, com. Potęgowo. They were these discoveries that permitted so called 
Lupawa industry to be assigned. Its distinctiveness, as compared to the other groups of TRB, was interpreted as a result, mainly, of specific features of raw material, i.e. Pomeranian flint, which imposed a widespread use of a splintering technique, and majority of products obtained were small in size.

The aim of the article has been to investigate the relationship between the flint working of the communities of the Lupawa group and populations representing the TRB in Kujawy. Such a comparisons became possible with the discoveries at Wilkostowo 23/24 site, com. Aleksandrów Kujawski. Nowadays, they provide the most valuable evidence for the characteristic of the flint working of communities inhabiting the great-valley area within the Polish Plain and representing the Classic Wiórek phase. While comparing flint artefacts from Wilkostowo 23/24 and Poganice 4 numerous common features might be observed, as well as several distinctive ones. What the two sites share is mainly good recognition of local raw materials and their intensive use, and, in terms of applied flintknapping method, dominance of the splintering technique (Fig. 1, 5).

As the most important differences between the analysed sites should be mentioned relatively high percentage of southern raw materials (so called Volhynian and chocolate flint) in inventories from Wilkostowo 23/24 site and a clear preference of flaking and blade-making techniques. On the other hand, within the settlement at Poganice site 4, almost exclusively (with the only exception of a flake made of Volhynian flint) various kinds of Baltic flint were used, of which the most important appeared to be Pomeranian flint. Classic coring techniques were used rarely.

At both sites almost the same categories of tools have been observed, while their number significantly differed. Within the settlement in Poganice particularly characteristic category were end scrapers on flakes of Pomeranian flint (Fig. 6). On the other hand, at site 23/24 in Wilkostowo a distinguishing category were macrolithic forms made of southern raw materials, including convergent retouched blades of Volhynian flint (Fig. 3).

It seems that features shared by both analysed assemblages may be considered distinguishing ones of flint working of the TRB communities inhabiting lowlands. The characteristic feature of this flint working would be its flexibility and ease in adapting to different ecological and cultural conditions. It is illustrated, among others, by popularity of the splintering technique applied for local raw material working, whilst, depending on the needs, a set of products of splintering and flake techniques might have been supported by imports of blades and blade tools made of the southern raw material (especially numerous at Wilkostowo 23/24 site - Fig. 2-3) or of better varieties of the Baltic flint (a small number of blade tools at site Poganice 4 - Fig. 8).

The observed quantitative variability within flint tools between the two sites, most probably, resulted from different economic strategies. Within the settlement at Wilkostowo 23/24 the essential were agrarian activities, which has been reflected in an inventory of flint tools: retouched blades, usable blades, implements with sickle gloss. On the other hand, the dominant group of tools within the settlement at Poganice site 4, numerous end scrapers, may reflect a prevailing role of animal breeding in the economy of its inhabitants. 